\title{
Cost on Equity in the Condition of SMEs in the Czech Republic: A Preliminary Study
}

\author{
Dana KUBÍČKOVÁ, Vladimír NULÍČEK \\ University of Finance and Administration, Prague, Czech Republic \\ dana.kubickova@centrum.cz, vnulicek@gmail.com
}

\begin{abstract}
This paper is focused on the cost of equity in SMEs in conditions of the transitional economic in the Czech Republic. The research question is what the actual level of this indicator in conditions of the different segments of SMEs is and how is in large companies. The second question is whether there are any differences between the three segments of SMEs and between SMEs and large companies. The third question is whether the level of equity cost differ in the different branches in which the SMEs operate. And the last question is whether the equity cost is affected by selected factors. The research is based on the set of 16,302 companies data of which were obtained from the Albertina database. The results confirmed the findings of previous research: the highest costs are associated with the capital employed in micro and small firms and in the field of Accommodation, meals and hospitality. The factor affecting the level of the equity cost was identified the volume of sales achieved. The results are limited by many factors however they can contribute to the overall view of the capital employment in the Czech Republic as the transition economy and as an introduced study for the next research as well as for practice of companies.
\end{abstract}

Keywords: Cost of Equity, SMEs, Risk Premium, Modular Method.

\section{Introduction}

The estimation of equity capital costs for corporations is close to the indicator of the economic value added as a modern tool for evaluating business performance. Although this indicator is associated with the development of financial theory at the end of the 20th century, the idea of equity cost and economic profit is older and is associated with the names of A. Marshall, L. Walras and others [25]. The idea of equity cost arose from the thought that the capital use in specific conditions should bring at least as much as it can be obtained by using the same amount of the capital in other conditions with the same risk, in the other words by using it in another area, taking into account the level of risk [12, 17, 8].

Cost of equity reflects the return on "unrealized, missed opportunities" plus the risk premium associated with the specific area of capital use. This approach became the basis for one of the methods quantifying the cost of equity $\left(\mathrm{r}_{\mathrm{e}}\right)$ where the profitability 
of risk-free investment (capital use - $r_{f}$ ) is increased by the risk premium corresponding to the degree of risk exposure $\left(\mathrm{r}_{\mathrm{POD}}\right)$ - see equation (1):

$$
r e=r f+r P O D
$$

The equity cost indicator can be considered as an objectified performance of capital in relation to the conditions of its use, a normative performance. The difference between this and the actual performance is an information for both the internal and the external performance evaluators of a particular company. This point of view became the base for our analysis.

The decomposition of the risks which are to be reflected in the risk premium in the calculation is the corner stone of the indicator cost of equity practical calculation. There are many theories and approaches which are subjects of a number of studies and researches.

Specific question is the determination of $r_{e}$ in condition of emerging countries. The economy of these countries is in the process of transition to the market principles and it brings many specific factors to the economic system and economic processes. These imperfections bring into the practice and behaviour of the firms some specifics which form a specific structure of business risks, which are commonly called as country risk. It exposes investor to additional risks. The breakdown of this risk into the specific types of risk has been carried out differently by different authors. Boyer et al. (Boyer et al. 2017) defined the risks in emerging markets in the areas as follows:

- Financial markets which are illiquid and lack transparency,

- Less developed regulatory, corporate governance and legal framework,

- Inability to repatriate earnings,

- Economic uncertainty,

- War and/or political instability,

One of the many questions is which of the risks do investors demand compensation for and how much additional return is required.

The aim of our research is to find out the actual level of the equity cost in conditions of the different segments of SMEs in the Czech Republic as a transition economy and to find out if there are any differences in the level of this indicator in the segment of SMEs and in large companies and in different branches. The results may become a basis for further examination of the cost of equity and its use in the Czech Republic.

Based on earlier empirical research, the following hypotheses can be formulated:

- The amount of capital costs will be highest in the segment of micro and small firms whose activities can be expected to have the highest level of risk

- The amount of capital costs depends inversely on the amount of the company's debt - the higher debt ratio is usually associated with a higher level of risk.

- The amount of capital costs depends inversely on the size of the firm - it can be assumed that with the growing size of the firm, the level of risk decreases, 
- The amount of capital costs depends inversely on the size of the company's sales - it can be assumed that the higher sales volume reflects the stronger position of the company and hence the lower risk.

\section{Literature review}

The interest of economic practice in the application of EVA has opened up a number of questions and has stimulated a number of research projects. They deal with the various aspects of the cost of equity, most often the methodology how to determine the amount of capital costs is discussed. In the literature two approaches are employed: One relies on the theoretical link between future realized returns and the cost of equity, the second relies on the theoretical link between the cost of equity capital and the priced risk. Many other researchers have attributed the cost of equity capital to various factors that affect the amount of capital costs. They analyze the role of corporate governance, IFRS implementation, audit firms, voluntary disclosure, financial leverage [24, 3, 16, 5, 7, 10, 13, 18, 21, 24, 28]. Many researchers deal with the level and role of this indicator in the specific national conditions $[15,9,17,19]$. They conclude, the high level of equity cost is a constraint as well as great differences between the costs of equity in the national economies $[12,15,31]$.

Another line of research focuses on the application and determination of cost of capital in emerging countries [18, 21, 6, 9]. Their goal is to verify the possibility of methods used to determine the cost of equity in the condition of emerging economies and its reliability in the given conditions or in a special branches [1, 17, 9] or segments of firms [21, 26]. The other researchers try to define a specific model suitable for these specific conditions [17, 20, 22, 23].

In the Czech Republic, much attention is paid to the costs of equity, particularly in the field of practical application. However, the underdeveloped capital market and the transition economy create relatively little scope for this research. The principle and the calculation of economic value in conditions of Czech enterprises are dealt with the authors, i.e. [22, 23, 30]. Extensive research on the level of cost of capital and EVA value was carried out at the end of $90^{\text {th }}$ and the results are presented in [11]. This issue is also dealt with some other young researches [2, 19].

At the end of the 90s, a model of the authors I. and I. Neumaier was created for the Czech condition. The aim was to allow the quantification of the risks of capital use in an individual company $[22,23]$. This system is designed for economic practice for benchmarking purposes. It is based on the modular method, i.e. the return on risk-free investment is increased by a risk premium. For the purposes of the risk premium calculation, this is divided into four sub-indices. For the calculation of these indices, the data of accounting statements compiled according to Czech accounting standards are consistently used. Although this concept does not eliminate the problem of reliability and differences in accounting data, a single, uniform base for benchmarking the performance of capital in the conditions of specific national economy was created which serves for the companies' comparison. 
Based on the literature review, it can be stated that the literature examined so far has not paid much attention to the issue of SMEs as a specific area of the economy. And in the Czech contexts, factors that can affect the level of equity costs have not been explored in more detail. This has become a stimulus for our research, to which the introductory study contains this article.

\section{Research Methodology and the Sample}

\subsection{Model re calculation}

In the Czech Republic the low level of capital market does not allow to measure effectively the real level of the risks which the equity undergo in the specific segments and branches. This fact was one of the incentives creating of a specific calculation model which was created by Inka and Ivan Neumaier, designated as INFA model. This model is available on the website of Ministry of Industry and Trade of the Czech Republic [14]. In our research we utilized this model to calculate the cost of equity employed in companies operating in different segments and industries.

Model INFA uses the following expression:

$$
r_{e}=r_{f}+r_{L A}+r_{P O D}+r_{F I N S T A B}+r_{F I N S T R U}
$$

where:

- $r_{e}-$ costs of equity,

- $r_{f}$-risk-free rate,

- $r_{L A}-$ risk premium for the size of the company or liquidity of the shares,

- $r_{P O D}-$ risk premium for business risk,

- $r_{\text {FINSTAB }}$ - risk premium for financial stability,

- $r_{F I N S T R U}-$ risk premium for financial structure.

The risk-free rate $\left(\mathrm{r}_{\mathrm{f}}\right)$ is derived from the yield of 10-year government bonds. Its values are published on the website of the Ministry of Industry and Trade (MIT). In the period 2015-2016, the risk-free rate was $0.58 \%$ and $0.48 \%$ respectively.

The risk premium for the size of company (or liquidity of shares $-r_{L A}$ ) depends on the size of so-called "available resources" (or charged resources - UZ), which is a summary of equity, bank loans and bonds. If it exceeds the amount of 3 bilions, the risk premium is $0 \%$, if the amount is lower than 100 milion, the risk premium is $5.00 \%$, if the amount is between 3 bilions and 100 milion, than the risk premium is calculated as $(3-U Z)^{2} / 168.2$.

The risk premium for business risk $\left(r_{P O D}\right)$ is dependent on the indicator of production power ROA (=EBIT/A), which is compared with the indicator $x_{1}$ calculated as follows:

$$
x_{1}=(\text { available resources / assets }) * U M
$$

where $U M=$ interest/(bank loans+long term liablities incl.financial ĺease). 
If $R O A$ is greater than $x_{1}$, then $r_{P O D}$ is the minimum of the $r_{P O D}$ in the industrial sector, if $R O A$ is lower than 0 , then $r_{P O D}$ is $10 \%$. If the $R O A$ is between these values, $r_{P O D}$ is calculated according to special formula:

$$
r P O D=\{(x 1-R O A) 2 / x 12\} * 0,1
$$

The risk premium for financial stability $\left(r_{\text {FINSTAB }}\right)$ depends on the ability to settle liabilities, on liquidity: the value of current liability $(C L)$ is compared with the recommended limits of $C L$, i.e. $1.0-2.5$. If $C L$ is lower than this interval, the risk premium is $10 \%$, if $C L$ is higher, the risk premium is $0 \%$, if $C L$ is in this interval, the risk premium is calculated according the formula:

$$
(2.5-C L) 2 /(2.5-1.0) 2 * 0.1
$$

Boundary values of the interval may be replaced in the individual calculation by values obtained in the sector.

The risk premium for financial structure $\left(r_{\text {FINSTRU }}\right)$ is the difference between $r_{e}$ and $W A C C$ : if these variables are equal, the risk premium is $0 \%$. The maximum allowed value is $10 \%$ [15].

\subsection{Structure of the sample and data source}

As data source for the calculation of $r_{e}$ we used the financial statements of the analyzed firms, which we obtained from the database of Albertina. The selected file included in total of 16,302 companies. More detailed information about the structure of the sample of the companies with regard to segments and industries is given in Table 1. Wholesale a retail trade and manufacturing companies represent the largest share according to branch structure, small companies represent the largest share according to segments structure.

Table 1. The structure of the sample

\begin{tabular}{lccccc}
\hline \multicolumn{1}{c}{ Segment } & Micro & Small & Medium & Large & Total \\
\hline Administrative and support activities & 294 & 418 & 89 & 26 & 827 \\
$\begin{array}{l}\text { Professional, scientific and } \\
\text { Technical activities }\end{array}$ & 851 & 554 & 112 & 41 & 1608 \\
$\begin{array}{l}\text { Real estate activities } \\
\text { Information and communication }\end{array}$ & 339 & 205 & 50 & 6 & 600 \\
$\begin{array}{l}\text { activities } \\
\text { Accommodation, meals and }\end{array}$ & 170 & 278 & 102 & 35 & 580 \\
hospitality & 376 & 326 & 56 & 7 & 765 \\
$\begin{array}{l}\text { Transport and storage } \\
\text { Wholesale and retail trade; }\end{array}$ & 146 & 558 & 106 & 64 & 974 \\
repair of motor vehicles & 949 & 2355 & 949 & 217 & 6593 \\
Construction & 488 & 866 & 215 & 47 & 1616 \\
Water supply, waste and & 32 & 129 & 68 & 29 & 258
\end{tabular}


sanitation

Electricity, gas, steam and air conditioning supply

Manufacturing

Total

\begin{tabular}{rrrrr}
9 & 53 & 40 & 50 & 152 \\
748 & 1912 & 1314 & 595 & 4669 \\
4402 & 7654 & 3129 & 1117 & 16302 \\
\hline
\end{tabular}

\section{Research results}

Based on the financial statements data and INFA model the indicator re was calculated for each company. The statistic characteristics of the re values reached in the sample are presented in table 2 . The average values of re are relatively high in all segments of firms, they are in the range of $24 \%$ and $35 \%$. The highest level of re was found in the segment of micro-enterprises, the lowest level in the segment of large companies. This result is in line with the first hypothesis assuming - the highest risks and the highest cost of equity were found in the segment of smallest (micro) firms.

Table 2. Value of re in the segments of SMEs and in the large companies - statistical characteristics.

\begin{tabular}{lllll}
\hline Segment & Micro & Small & Medium & Large \\
\hline Median $r_{e}$ & 0.2296 & 0.1858 & 0.1517 & 0.1315 \\
Min $r_{e}$ & 0.0558 & 0.0447 & 0.0209 & -0.0162 \\
Max $r_{e}$ & 9.9215 & 9.9344 & 9.8425 & 9.7387 \\
Average & 0.3553 & 0.3129 & 0.2861 & 0.2479 \\
\hline
\end{tabular}

More detailed information of the level of capital costs in Czech companies provides their breakdown by subject area/branches defined according to NACE - they are presented in table 3 . The highest average value of the equity cost $\left(r_{e}\right)$ was found in the branch of Electricity, gas, steam and air conditioned supply in the segment of micro firms and in the branch of Accommodation, meals and hospitality, which is relatively high in all segments. But the highest level is surprisingly in the segment of large and medium companies. The relatively high level of the equity cost was found in the branch of Real estate activities in the segment of small companies. It can be considered as the reflection of the branch specifics in the segment of small firms. Relatively high level of the equity cost was identified in the branch of Electricity, gas and steam production in the segment of micro firms. It can be also considered as the reflection of the branch specifics, which is too demanding compared to the microfirms conditions. 
Table 3. Value of $r_{e}$ in the branches according to segments of SMEs and in large companies

\begin{tabular}{|c|c|c|c|c|c|c|c|c|}
\hline \multirow{2}{*}{$\begin{array}{l}\text { Segment } \\
\text { Branch }\end{array}$} & \multicolumn{2}{|c|}{ Micro } & \multicolumn{2}{|c|}{ Small } & \multicolumn{2}{|c|}{ Medium } & \multicolumn{2}{|c|}{ Large } \\
\hline & median & average & median & average & median & average & median & average \\
\hline $\begin{array}{l}\text { Administrative and } \\
\text { support activities }\end{array}$ & 0.2127 & 0.2935 & 0.1558 & 0.2480 & 0.1235 & 0.2556 & 0.1312 & 0.2532 \\
\hline $\begin{array}{l}\text { Professional, } \\
\text { scientific and } \\
\text { technical activities }\end{array}$ & 0.2106 & 0.2745 & 0.1783 & 0.2487 & 0.1558 & 0.2742 & 0.1378 & 0.1514 \\
\hline Real estate activities & 0.2558 & 0.4447 & 0.1935 & 0.6614 & 0.1759 & 0.5068 & 0.7252 & 0.7870 \\
\hline $\begin{array}{l}\text { Information and } \\
\text { communication }\end{array}$ & 0.1968 & 0.3130 & 0.1875 & 0.2217 & 0.1553 & 0.1974 & 0.1525 & 0.2307 \\
\hline $\begin{array}{l}\text { Accommodation, } \\
\text { meals and } \\
\text { hospitality }\end{array}$ & 0.2858 & 0.4215 & 0.2510 & 0.5022 & 0.1776 & 0.8481 & 0.1427 & 1.0279 \\
\hline $\begin{array}{l}\text { Transport and } \\
\text { storage }\end{array}$ & 0.2299 & 0.4557 & 0.2017 & 0.2884 & 0.1723 & 0.2568 & 0.1705 & 0.2919 \\
\hline $\begin{array}{l}\text { Wholesale and } \\
\text { retail trade; repair } \\
\text { of motor vehicles }\end{array}$ & 0.2534 & 0.3663 & 0.1928 & 0.3180 & 0.1688 & 0.3011 & 0.1437 & 0.2202 \\
\hline Construction & 0.1976 & 0.3239 & 0.1826 & 0.2929 & 0.1458 & 0.2860 & 0.0959 & 0.1930 \\
\hline $\begin{array}{l}\text { Water supply, } \\
\text { waste and } \\
\text { sanitation }\end{array}$ & 0.1928 & 0.2648 & 0.1891 & 0.2993 & 0.1528 & 0.1486 & 0.1313 & 0.2142 \\
\hline $\begin{array}{l}\text { Electricity, gas, } \\
\text { steam and air } \\
\text { cond. supply }\end{array}$ & 0.2773 & 1.5965 & 0.1773 & 0.2056 & 0.1442 & 0.5445 & 0.1273 & 0.3259 \\
\hline Manufacturing & 0.1929 & 0.3833 & 0.1829 & 0.3076 & 0.1428 & 0.2622 & 0.1237 & 0.2452 \\
\hline
\end{tabular}

The values of the equity cost level $\left(r_{e}\right)$ in the sample are presented in table 4 , where the interval distribution of the values is performed. Most firms reached the cost of equity value in the interval of $10 \%-29 \%$. Financial analysis of the business sphere for 2015 made by MIT CR shows the average value of $r_{e}$ in the same period in the average amount of $10.16 \%$. It is a little lower than the resulting values in our sample. The reason can be in the fact, that into the „business sphere“ there are included firms selected according to whether they form the value for owners, i.e. if the value of the indicator EVA is higher than 0. Due to the lower risks in such companies the value of equity cost is lower. Our results offer a more realistic statement about the situation in the companies in the Czech Republic.

The values of $r_{e}$ found in our study are relatively high, higher than in the selected firms in the study of the MIT CR - is corresponding to the complexity of the sample. The results thus can be considered as a complex reflection of the higher risk of the business in the transition economy (Boyer et al.) The structure according to the branches make this reflection more detailed. 
Table 4. Interval distribution of the $r_{e}$ in the sample and the segments of SMEs

\begin{tabular}{|c|c|c|c|c|c|c|c|c|c|c|c|}
\hline \multirow[t]{2}{*}{ Interval $r_{e}$} & \multicolumn{2}{|c|}{$=<0,09$} & \multicolumn{2}{|c|}{$0,10-0,29$} & \multicolumn{2}{|c|}{$0,3-0,49$} & \multicolumn{2}{|c|}{$0,5-0,99$} & \multicolumn{2}{|c|}{$>=1,0$} & \multirow{2}{*}{ Total } \\
\hline & abs. & $\%$ & abs. & $\%$ & abs. & $\%$ & $a b s$. & $\%$ & $a b s$. & $\%$ & \\
\hline Micro & 324 & 7.36 & 2950 & 67.01 & 936 & 21.26 & 34 & 0.77 & 158 & 3.59 & 4402 \\
\hline Small & 1258 & 16.74 & 5263 & 68.86 & 726 & 9.48 & 85 & 1.11 & 322 & 4.21 & 7654 \\
\hline Medium & 884 & 28.25 & 1898 & 60.67 & 201 & 6.42 & 32 & 1.02 & 114 & 3.64 & 3129 \\
\hline Large & 389 & 34.83 & 629 & 56.31 & 43 & 3.85 & 15 & 1.34 & 41 & 3.67 & 1117 \\
\hline Total & 2855 & 17.51 & 10740 & 65.88 & 1906 & 11.69 & 166 & 1.02 & 635 & 3.89 & 16302 \\
\hline
\end{tabular}

In the last step of this preliminary study we tested the link between the value of $r_{e}$ and selected indicators which could characterize in more details the condition of the firms operations. The idea was to analyze those characteristics that reflect the risks to which the equity have to face in the company. Based on the empirical findings we selected the indicators as follows: the volume of liabilities, the volume of assets, the volume of sales in absolutely amount and financial leverage as the ratio indicator representing the capital structure. The results of the analysis of correlation dependence between cost of equity and the selected indicators are presented in the table 5.

Table 5. Corellation $r_{e}$ and selected indicators in the segments of SME

\begin{tabular}{lllrr}
\hline $\begin{array}{l}\text { Correlation of } \\
\boldsymbol{r} \\
\text { in with: }\end{array}$ & Liabilities & Assets & Sales & $\begin{array}{l}\text { Financial } \\
\text { leverage }\end{array}$ \\
\hline Micro & 0.085803 & 0.010368 & -0.00182 & 0.013432 \\
Small & 0.092980 & 0.055660 & -0.05570 & 0.104296 \\
Medium & 0.184335 & 0.088171 & -0.05928 & 0.158886 \\
Large & 0.017020 & 0.017020 & -0.01781 & 0.127574 \\
\hline
\end{tabular}

The resulting values of correlation revealed overall a very low dependence between the cost of equity and selected indicators.

The correlation between the cost of equity $\left(r_{e}\right)$ and sales is relatively low but negative, i.e. the cost of capital is lower when the amount of sales is higher. It confirms empirical experiences when the sales represent a stable financial position in the market and thus lower level of risk. The differences between the segments are quite high. The highest dependence was detected in the segment of medium firms.

The correlation of $r_{e}$ and the volume of assets show relatively low level, but positive. This may be considered inconsistent with empirical experience, but it could be the reflection of the real conditions in these firms. The highest level was found in the segment of medium SMEs. These findings are relatively interesting due to the overall stability of firms in this segment as a result of the good equipment.

The correlation between $r_{e}$ and the liabilities is also very weak, but positive. The positive relation corresponds to the empirical experiences. But the significant role of 
debt in the financial stability of the company allows to expect the higher dependency and the stronger relation. The highest level of correlation was detected in the segment of medium sized companies.

More accurate statement of the effect of debt on the equity costs provides correlation of $r_{e}$ and financial leverage. The correlations values are not high, however, they are positive. It always reflects the negative impact of the debt on the financial stability resulting in the higher cost of equity. The highest value was found in the segment of medium SMEs.

\section{Conclusion and discussion}

Based on the analysis several conclusions can be formulated. The business risk in the Czech Republic as one of the emerging (transition) countries is relatively high. Consequently, the cost of equity (re) as the required return on capital is relatively high in the companies throughout the branches and across the segments. The highest values of the cost of equity were found in the segment of micro-firms and in the branch of hospitality and accommodation. From the four selected indicators the amount of liabilities and financial leverage was identified as the factor most affecting the cost of equity level. These findings are consistent with the formulated hypothesis and correspond to the empirical findings. The results also bring new findings in the field of differences among the segments of firms. A significant difference has been revealed between micro and small enterprises on the one side and medium and large enterprises on the other. The differences between SMEs and large companies are not so great. In the segments of SME's the position of the medium sized companies is closer to the large companies.

The results of our analyses have some limitation. The first limitation lies in the sample and data used for the calculation. Financial statements based on the Czech accounting standards do not provide a reliable information of the companies' economic situation. The next limitation (besides it can be considered as an advantage) lies in the method of calculation, which is based only on the financial data, not on the capital market and market data. The values of cost on equity are not fully the objective information. But on the other hand, these data are uniform and provide the unified bases for the inter-company comparison. The final reservation can be expressed to the risk decomposition, included into calculation, which do not sufficiently reflect real business risks in the transition economy.

Acknowledgements. The authors acknowledge the institutional support for long-term strategic development of research organization University of Finance and Administration, Prague. 


\section{References}

1. Asal, M.: Estimating the Cost of Equity Capital of the Banking Sector in the Eurozone. Journal of Applied Finance and Banking 5(6), 69-96 (2015).

2. Beranová M., Basovníková, M., Martinovičová, D.: Problematické aspekty ukazatele ekonomické přidané hodnoty $\mathrm{v}$ podmínkách $\mathrm{CR}$. Acta universitatis agriculturae et silviculturae mendeleanae brunensis 58(6), 59-66 (2010), DOI: 10.11118/ actaun201058060059.

3. Botosan, Ch. A., Plumlee, M. A., Wen, He.: The Relation between Expected Returns, Realized Returns, and Firm Risk Characteristics. Contemporary Accounting Research 28(4), 1058-1085 (2011), DOI: 10.1111/j.1911-3846.2011.01096.x.

4. Boyer, B., Lim, R., Lyons, B.: Estimating the Cost of Equity in Emerging Markets: A Case Study. American Journal of Management 17(2), 58-64 (2017).

5. Cao, Y., Myers, J. N., Myers, L. A., Omer, T. C.: Company reputation and the cost of equity capital. Review of Accounting Studies 20(1), 42-81 (2015), DOI: 10.1007/s11142014-9292-9.

6. Coffie, W., Chukwulobelu, O.: The Cost of Equity Capital in Emerging Market - The Case of Kenya. GSTF Business Review 2(4), 192-200 (2013). DOI: 10.5176/20104804_2.4.270.

7. Cuadrado-Ballesteros, B., Garcia-Sanchez, I.-M., Martinez F. J.: How are corporate disclosures related to the cost of capital? The fundamental role of information asymmetry. Management Decision 54(7), 1669-1701 (2016), DOI: 10.1108/MD-10-2015-0454.

8. Damodaran, A.: Measuring company exposure to country risk: theory and practice. Journal of Applied Finance 13(September 2003), 63-75 (2003).

9. Demir, S. A., Yasemin C. K.: The Effects of International Integration on Cost of Equity: Application of Turkey's Tourism Sector. Muhasebe ve Finansman Dergisi 66(April 2015), 193-208 (2015).

10. Dhaliwal, D. S., Li, O. Z., Tsang, A., Yang, Y. G.: Voluntary Nonfinancial Disclosure and the Cost of Equity Capital: The Initiation of Corporate Social Responsibility Reporting. The Accounting Review 86(1), 59-100 (2011), DOI: 10.2308/ accr.00000005.

11. Dluhošová, D.: Finanční řízení a rozhodování podniku. 3rd edn. Ekopress, Prague (2010).

12. Dolde, W., Giaccotto, C., Mishra, D. R., O'Brien, T.: Should managers estimate cost of equity using a two-factor international CAPM? Managerial Finance 38(8), 708-728 (2012), DOI 10.1108/03074351211239360.

13. Fernando, G. D., Abdel-Meguid, A. M., Elder, R. J.: Audit quality attributes, client size and cost of equity capital. Review of Accounting \& Finance 9(4), 363-381 (2010), DOI: 10.1108/14757701011094571.

14. Financial Analysis of the Business Sphere for the Year 2015, http://www.mpo.cz. Last accessed 2017/09/26.

15. Foong, S. S., Goh, K. L.: Measuring the cost of equity of emerging market firms: the case of Malaysia. Asian Academy of Management Journal of Accounting and Finance 6(1), 2546 (2010).

16. Hail, L., Leuz, C.: International differences in the cost of equity capital: do legal institutions and securities regulation matter? Journal of Accounting Research 44(3), 485531 (2006), DOI: 10.1111/j.1475-679X.2006.00209.x.

17. Kanaryan, N. K., Chuknyisky, P., Kasarova, V.: The cost of equity estimation in emerging Europe: the case of Bulgarian REITs. Journal of Property Investment \& Finance 33(6), 517-529 (2015), DOI: 10.1108/JPIF-05-2015-0028. 
18. Khlif, H., Samaha, K., Azzam, I.: Disclosure, ownership structure, earnings announcement lag and cost of equity capital in emerging markets: The case of the Egyptian stock exchange. Journal of Applied Accounting Research 16(1), 28-57 (2015), DOI: 10.1108/ JAAR-06-2012-0046.

19. Kislingerová, E. et al.: Manažerské finance. 3rd edn. Wolters Kluwer. Prague (2010).

20. Kolouchová, P., Novák, J.: Cost of Equity Estimation Techniques Used by Valuation Experts. IES Working Paper, 8 (2010).

21. Kumar, P., Firoz, M.: The impact of voluntary environmental disclosure on cost of equity capital - evidence from Indian firms. Journal of Contemporary Management Research 11(1), 1-26 (2017).

22. Neumaier, I., Neumaierová, I.: Why took the IN index and not a pyramidal system of indicators INFA. E+M Economics and Management 4(2), 10-22 (2008).

23. Neumaierová, I., Neumaier, I.: INFA Performance Indicator Diagnostic System. Central European Business Review 3(1), 35-41 (2014), DOI: 10.18267/j.cebr.73.

24. Pettengill, G. N., Lander, D. M.: Response of the Cost of equity to leverage: and alternative perspective. Journal of Business Strategies 32(2), 110-138 (2015).

25. Procházka, D.: Determinace zisku v účetnictví a ekonomii. 1st edn. Vysoká škola ekonomická, Prague (2012).

26. Ranosz, R.: Analysis of the structure and cost of capital in mining enterprises. Gospodarka Surowcami Mineralnymi 33(1), 77-92 (2017). DOI: 10.1515/gospo-2017-0001.

27. Sabal, J.: Financial Decisions in Emerging Markets. 1st edn. Oxford University Press, New York (2002).

28. Setiany, E., Suhardjanto, D., Lukviarman, N., Hartoko, S.: Board Independence, Voluntary Disclosure, and the Cost of Equity Capital. Review of Integrative Business and Economics Research 6(4), 389-399 (2017).

29. Stehel, V., Vochozka, M.: Company Management by Using INFA Method. In: Rotschedl, J., Čermáková, K. (eds.) Proceedings of the 12th International Academic Conference, Prague, September 2014, pp. 1132-1144. International Institute of Social and Economic Sciences, Prague (2014).

30. Vochozka, M.: Development of Methods for Comprehensive Evaluation of Business Performance. Political Economy 5(58), 675-688 (2010), DOI: https://doi.org/10.18267/j.polek.754.

31. Zorn, L.: Estimating the Cost of Equity for Canadian and U.S. Firms. Bank of Canada Review Autumn 2007(October 2007), 27-35 (2007). 